\title{
FUNCTIONAL STOMATA OF THE ATMOSPHERIC EPIPHYTE TILLANDSIA USNEOIDES L. ${ }^{1}$
}

\author{
CRAIG E. MARTIN AND ERIC A. PETERS \\ Department of Botany, University of Kansas, Lawrence, Kansas 66045
}

\begin{abstract}
Although stomatal opening in Tillandsia usneoides is not detectable by light microscopy, the guard cells swell in the dark and in the light in buffers known to stimulate stomatal opening. Abscisic acid or phenylmercuric acetate substantially reduced subsequent nocturnal $\mathrm{CO}_{2}$ uptake. Potassium ions were more concentrated in the guard cells in the dark than in the light. The stomata of this CAM epiphyte appear functional: open at night and closed throughout most of the day.
\end{abstract}

\section{Introduction}

Lack of functional stomata in Tillandsia usneoides was first reported by MEZ (1896). BILLINGS (1904) subsequently supported this claim with the following evidence: (1) purported immobility of the guard cells as a result of their extremely thick walls, (2) failure to detect visibly open stomata, and (3) failure of attempts to induce stomatal opening (BILlINGS 1904). Conversely, ToMLINSON (1969) suggested that guard cells of this epiphyte might be permanently open as a hygromorphic feature, supposedly to promote an increase in transpiration and subsequent uptake of elemental nutrients. Downs (1974) also discussed the possibility that the stomata of $T$. usneoides are permanently open. Evidence for the total absence of stomata in other atmospheric bromeliads was provided by LiNsBAUER (1911).

MARTIN (1982) reported that the stomata of $T$. usneoides were nonfunctional: (1) with light microscopy, open stomata were not seen in live material, which had been treated to stimulate stomatal opening; (2) high concentrations of $\mathrm{CO}_{2}$ did not inhibit the rates of nighttime ${ }^{14} \mathrm{CO}_{2}$ uptake in this CAM plant; (3) ABA did not reduce nocturnal net $\mathrm{CO}_{2}$ uptake; and (4) gas diffusion resistance analyses demonstrated that $\mathrm{CO}_{2}$ and $\mathrm{H}_{2} \mathrm{O}$ vapor were diffusing along different pathways. COCKBURN (1983) viewed these findings as evidence for a potentially novel variation on the CAM theme.

The only evidence for functional stomata in atmospheric bromeliads was found in studies of $\mathrm{CO}_{2}$ exchange patterns. In the two species studied, a typical CAM $\mathrm{CO}_{2}$ exchange pattern was observed: stomata open at night and close throughout most of the day (KLUGE et al. 1973; LANGE and MEDINA

\footnotetext{
${ }^{1}$ Abbreviations: ABA, abscisic acid; CAM, Crassulacean acid metabolism; Chl, chlorophyll; DMSO, dimethylsulfoxide; D/ $\mathrm{N}$, day/night; DW, dry weight; MES, 2-morpholinoethanesulfonic acid; PMA, phenylmercuric acetate; PPFD, photosynthetic photon flux density; RH, relative humidity.

Manuscript received December 1983; revised manuscript received April 1984.

Address for correspondence and reprints: C. E. MARTIN, Department of Botany, University of Kansas, Lawrence, Kansas 66045.
}

1979; MarTin et al. 1981; MARTIN and Siedow 1981). Also, nocturnal $\mathrm{CO}_{2}$ exchange rates were sharply diminished by abrupt decreases in atmospheric RH in $T$. recurvata (LANGE and MEDINA 1979) and in T. usneoides (MARTIN and SIEDOW 1981). Such responses have been attributed to rapid stomatal closure in other CAM and non-CAM species (LANGE et al. 1971; OSMOND et al. 1979; BUNCE 1981).

Given the conflicting evidence regarding the functionality of stomata in atmospheric bromeliads, particularly $T$. usneoides, we wished to determine whether the stomata of $T$. usneoides are functional. Our results indicate that the stomata of this epiphyte function normally.

\section{Material and methods}

Tillandsia usneoides was collected from several trees ca. $50 \mathrm{~km}$ north of Corpus Christi, Texas, in June 1982, transported to Kansas, and hung from wood and wire in a greenhouse at the University of Kansas. Plants were watered several times each week and occasionally sprayed with a dilute nutrient solution. Environmental conditions in the greenhouse in the winter and spring of 1983 when this study was undertaken were: maximum PPFD from above, ca. $500 \mu \mathrm{mol} \cdot \mathrm{m}^{-2} \cdot \mathrm{s}^{-1}$; maximum D/ $\mathrm{N}$ air temperatures, $35 / 20 \mathrm{C}$; and $\mathrm{RH}$, ca. $40 \%$ / $80 \%$. Photoperiod was extended $5 \mathrm{~h}$ with fluorescent lamps.

Two T. bryoides plants were purchased from Tropical Imports (Coarsegold, Calif.) in June 1983. They were collected in June 1982 in Argentina.

\section{MICROSCOPIC OBSERVATIONS}

To facilitate observation of the stomata, trichome shields were removed from the leaves by the repeated application and removal of adhesive tape. In the late afternoon or early evening, leaves were detached and soaked in one of the following solutions: (1) $0.01 \mathrm{M}$ citrate, $0.02 \mathrm{M} \mathrm{Na}_{2} \mathrm{PO}_{4}, \mathrm{pH}$ 3 (JINNO and KURAISHI 1982), (2) 0.01 M PIPES, $0.0176 \mathrm{M} \mathrm{KCl}, 10^{-4} \mathrm{M}$ kinetin (JEWER and INCOLL 1981), or (3) $0.08 \mathrm{M} \mathrm{KCl}, 0.025 \mathrm{M} \mathrm{MES}, \mathrm{pH} 6.3$ (ZEIGER et al. 1983). All leaves were soaked for 2 $\mathrm{h}$ under either room light or in the dark. Controls 


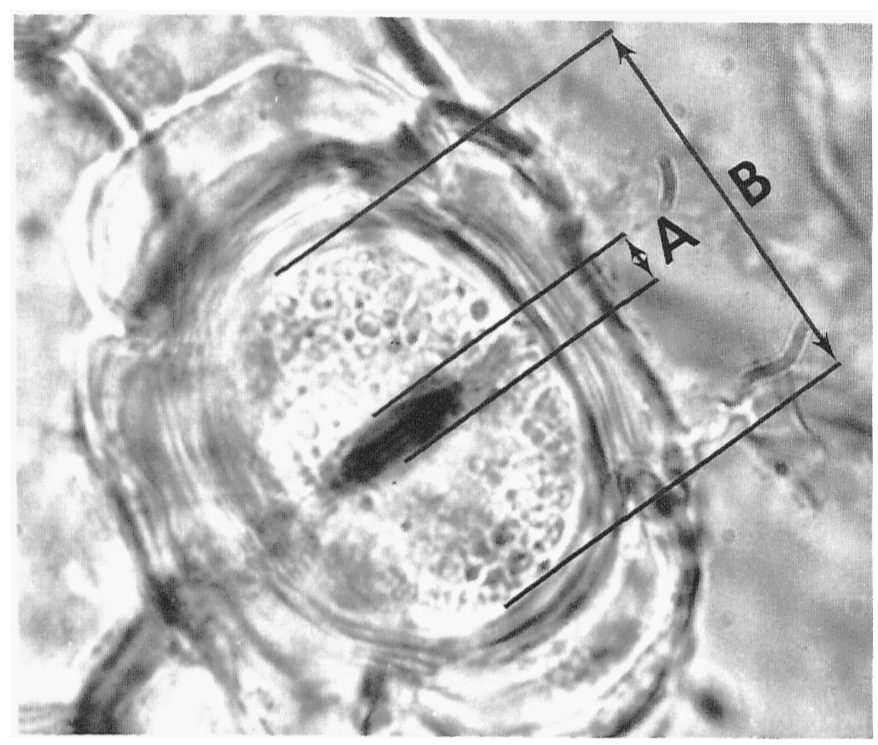

FIG. 1.-Dimensions of stomatal complex measured on the surface of Tillandsia usneoides leaves after various treatments designed to open and close the stomata. Whole leaves were mounted in water after removal of trichomes. The stomate is ca. 50 $\mu \mathrm{m}$ wide.

were soaked in deionized water.

After soaking, random stomata on each leaf were measured at $\times 400$ using an ocular scale on a Leitz compound microscope. As an indicator of stomatal opening, the distance between the guard cell inner walls ( $A$ in fig. 1) was divided by the width of the entire stomatal complex (distance between guard cell outer walls, $B$ in fig. 1).

For anatomical observations, leaves of $T$. usneoides were fixed in formalin-acetic acid, dehydrated in a graded series of water-ethanol, embedded in paraffin, sectioned, and stained with safranin and fast green.

\section{GAS EXCHANGE EXPERIMENTS}

An open, differential infrared gas analysis system monitored $\mathrm{CO}_{2}$ and $\mathrm{H}_{2} \mathrm{O}$ exchange, and leaf and air temperatures (MARTIN and ZEE 1983). The plant chamber was constructed of polycarbonate, which has lower $\mathrm{CO}_{2}$ and $\mathrm{H}_{2} \mathrm{O}$ absorption characteristics than does Plexiglas (MODERN Plastics ENCYCLOPEDIA 1980, pp. 535, 547). Air mixing within the chamber was provided by a Micronel U.S. fan (Model V241L; Fallbrook, Calif.), which does not alter the gas composition of the chamber (BINGHAM and COYNE 1977). The fan created air turbulence within the clump of $T$. usneoides at rates up to $0.15 \mathrm{~m} \cdot \mathrm{s}^{-1}$. Clumps of $T$. usneoides (ca. 2 $\mathrm{g} \mathrm{DW})$ were completely sealed in this chamber (0.8liter volume). Although this bulk of plant material in the chamber resulted in considerable self-shading and thick boundary layers, large samples were necessary to obtain reasonable rates of $\mathrm{CO}_{2}$ exchange because of the slow rates typical of this CAM

TABLE 1

Chancies in STOMATAL. DIMENSIONS FOR L.EAVES OF TILlandSia USNEOIDES AFTER SOAKING $2 \mathrm{~h}$ IN THE SOLUTION SHOWN

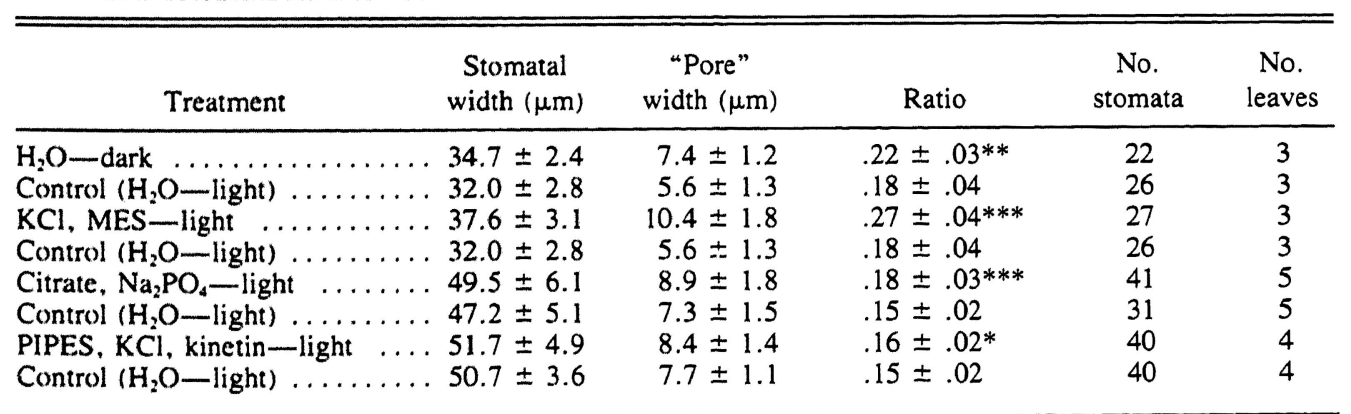

NoTt. - Ratios are "pore" widths divided by stomatal widths (see fig. 1). Levels of significance are results of $t$-tests comparing the mean ratios of each treatment and its control.

$* P<.05$.

$* * P<.01$

$* * * P<.001$. 
epiphyte (KLUGE et al. 1973; MARTIN and SIEIDOW 1981). In spite of this, rates of $\mathrm{H}_{2} \mathrm{O}$ exchange (loss from plant during day, uptake at night) were barely detectable and not quantifiable. In all gas exchange experiments, chamber environmental conditions were: (1) PPFD inside the chamber ranged from 1,100 to $1,800 \mu \mathrm{mol} \cdot \mathrm{m}^{-2} \cdot \mathrm{s}^{-1}(12$-h photoperiod), (2) $\mathrm{D} / \mathrm{N}$ air temperatures were $25 / 15 \mathrm{C}$. (3) daytime leaf temperatures were 4-5 $\mathrm{C}$ above air temperature, and (4) D/N air RH were $50 \% / 90 \%$ (MARTIN and ZEE: 1983).

Attempts to observe the effects of high $\mathrm{CO}_{2}$ concentrations on rates of nocturnal $\mathrm{CO}_{2}$ uptake as an indication of stomatal closure in $T$. usneoides were thwarted for the following reasons: (1) no decrease in $\mathrm{CO}_{2}$ uptake was noted, probably because the steep gradient of external to internal $\mathrm{CO}_{2}$ concentration resulted in $\mathrm{CO}_{2}$ uptake rates large enough to compensate for any stomatal narrowing; and $(2)$ it was not possible to utilize the $\mathrm{H}_{2} \mathrm{O}$ exchange data because the rates were low and the bulk of $\mathrm{H}_{2} \mathrm{O}$ exchange probably represented hydration or dehydration of the very hygroscopic trichome shields.

For the ABA and PMA experiments, a clump of $T$. usneoides was wetted with a control solution of deionized water containing $0.01 \%$ (vol/vol) Triton $\mathrm{X}-100$ and $0.2 \%(\mathrm{vol} / \mathrm{vol})$ ethanol or DMSO. The clump was surface dried and inserted into the gas exchange chamber immediately before darkness. Following the nighttime period of $\mathrm{CO}_{2}$ uptake and the subsequent daytime period of little or no $\mathrm{CO}_{2}$ exchange, the clump was removed from the chamber, wetted with $10^{-4} \mathrm{M}( \pm$ ) cis-trans ABA (Sigma

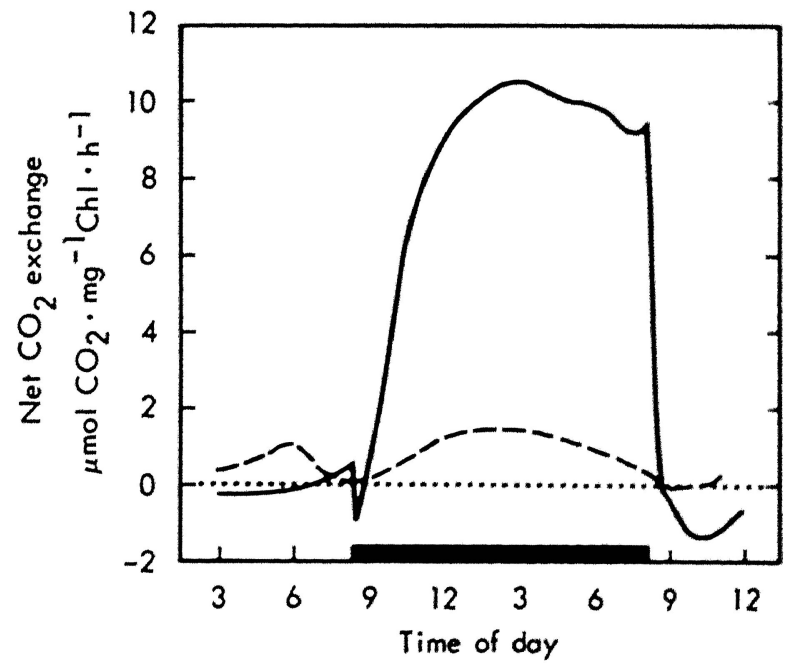

Fic; 2. - Effects of $\mathrm{ABA}$ on necturnal net $\mathrm{CO}$, exchange in Tillandsia usneoides. After the control solution was applied at 8 P.M. . $\mathrm{CO}_{2}$ exchange (solid line) was monitored for $24 \mathrm{~h}$ At 8 P.M. of the second day, the clump was wetted with $10^{*} \mathrm{M}$ $A B A$, and its $C O_{2}$ exchange (dashed line) was subsequently monitored. Curves represent mean $\mathrm{CO}_{\text {; }}$ exchange rates taken at 15 -min intervals with three different clumps of plant matc. rial. Standard deviations ranged from 0.06 to $2.85 \mathrm{ino}=204$ intervals). The black bar indicates darkness

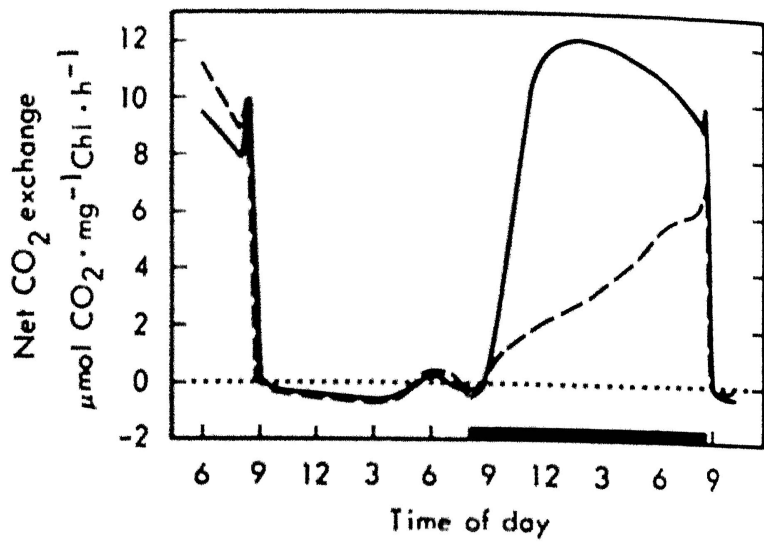

Fk, 3 - Lffects of PMA in noxturnal net ( $($ ); exchange in Tillandsu usneomels After the control wlution was applied at X P.M. . CO, exchange r wilid lines was monifured for $24 \mathrm{~h}$. At X P.M. of the eccond day. the clump was wetted with 10 ' $M$ PMA, and its (C), exchange dashed linel was subsequently monitured (curves tepresent mean ( $(1)$; exchange rates taken at 15 -min intervals with three different clump of plant matenal Standard deviatoms ranged ftom 1101 10 256 ino $=184$ intervalst The blach hat indicates datknese

Chemical. St. Louis) in $0.2 \%(\mathrm{vol} / \mathrm{vol})$ ethanol or $10^{-3} \mathrm{M}$ PMA (Sigma) in $0.2 \%(\mathrm{vol} / \mathrm{vol})$ DMSO and $0.01 \%$ (vol/vol) Triton X-100), air-dried, and placed hack into the chamber. Gas exchange was then monitored a second night. All procedures were carried out three times for cach experimental solution.

Following a gas exchange experiment, the clump of $T$. usneoides was removed. ground in $80 \%$ aquecous acetone in a Waring Blendor for $1 \mathrm{~min}$, extracted $2-3 \mathrm{~h}$, and vacuum filtered. The extract was analyzed spectrophotometrically for $\mathrm{Chl}$ content (ARNoN 1949),

\section{Potassitimioxal.zation}

Potassium ions were localized by precipitation as potassium cobaltinitritc $1 / 11$ MHit and HSIAO) 1970) and subsequently viewed microscopically. Leaves were stained after $3 \mathrm{~h}$ in the light or in the dark in late afternoon or carly evening. This was repeated three tumes

\section{Results}

Although open stomata of Tillandsia usneoides were never observed in fresh tissue under the light microscope, the shape of the stomatal complex enlarged in the dark and in the light when treated with buffers known to open stomata (table 1), relative to the controls in deionized water in the light. $V$ ariability in the dimensions of the stomata reflect stomatal size differences betucen strands of Spanish moss.

Daytime applications of either $10^{\circ} \mathrm{MABA}$ (fig. 2) or 10 'M PMA (fig. 31 resulted in a substantial reduction of $(\mathrm{O})$, uptake rates the following night. 


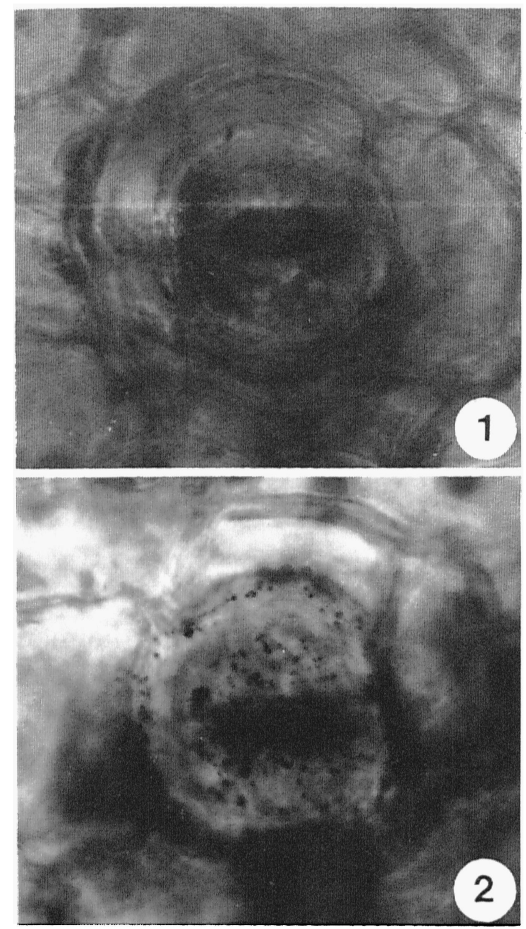

FIG. 4.-Potassium cobaltinitrite (black precipitate) localization in leaf epidermal cells of Tillandsia usneoides after $3 \mathrm{~h}$ in the light (l) or in the dark (2). The stomate is ca. $50 \mu \mathrm{m}$ wide.

Only the ABA-treated plants exhibited some recovery in $\mathrm{CO}_{2}$ uptake during the later part of the dark period.

Accumulation of the $\mathrm{K}^{+}$precipitation complex in the guard cells of $T$. usneoides occurred in the dark but not in the light (fig. 4). In the light, stain was not found in the stomata or in other epidermal cells; however, large quantities of stain were deposited in the trichome stalk cells (not shown), indicating that the staining technique worked properly.

\section{Discussion}

Although each experiment may not conclusively prove that the stomata of Tillandsia usneoides function normally, all of the evidence together strongly indicates normal CAM functioning. The guard cells enlarge when leaves are placed in the dark or in buffers that stimulate stomatal opening in other plants (JEWER and INCOLL 1981; JINNO and KURAISHI 1982; ZEIGER et al. 1983). Nocturnal $\mathrm{CO}_{2}$ exchange is inhibited by applications of ABA or PMA, which cause stomatal closure in other plants (SCHULT and DöRFFLING 1981; ZEIGER 1983). Finally, the guard cells accumulate large amounts of potassium during the night but not during the day. The lack of stain in closed stomata is not unusual and has been found in several $\mathrm{C}_{3}$ species after dark treatment (DAYANANDAN and KAUFMAN 1975). Thus, contrary to previous reports, these results in- dicate that the stomata of this atmospheric epiphyte are functional.

The absence of open stomata in this and previous studies (BILlINGS 1904; MARTIN 1982) does not preclude the possibility that the stomata open at night (though the stomatal pore is not perceptible by light microscopy) and close during the day, thus regulating gas exchange in typical CAM fashion. Visualizing stomatal opening may be hindered by the large antechambers characteristic of Spanish moss (fig. 5), as suggested by WEYERS and TRAVIS (1981). Furthermore, thick guard cell walls do not necessarily restrict movement of these cells, as proposed by BILLINGS (1904), since many taxa with functional stomata also exhibit very thick guard cell walls (WU and SHARPE 1980).

Most of the preliminary data obtained by MARTIN (1982) are compatible with our explanation, in spite of his tentative conclusion that the stomata of $T$. usneoides are nonfunctional. His observation, from gas resistance analysis, that $\mathrm{CO}_{2}$ and $\mathrm{H}_{2} \mathrm{O}$ vapor follow pathways of different resistances can be explained by the following: $\mathrm{CO}_{2}$ is taken up through the stomata at night while most of the $\mathrm{H}_{2} \mathrm{O}$ vapor is absorbed by the desiccated trichomes (PENFOUND and DEILER 1947; VIRZO DE SANTO et al. 1976). Thus, water loss through the stomata would be obscured by this water vapor uptake. The results of the ABA and PMA experiments in the current study contradict the lack of an ABA effect on nocturnal $\mathrm{CO}_{2}$ exchange found by MARTIN (1982). This discrepancy may be attributed to the forms of $\mathrm{ABA}$ utilized in the two studies: MARTIN (1982) used the "mixed isomers" form, which is less active than the "( \pm ) cis-trans" form (MARTIN, personal observation).

$\mathrm{ABA}$ and PMA may have inhibitory effects on

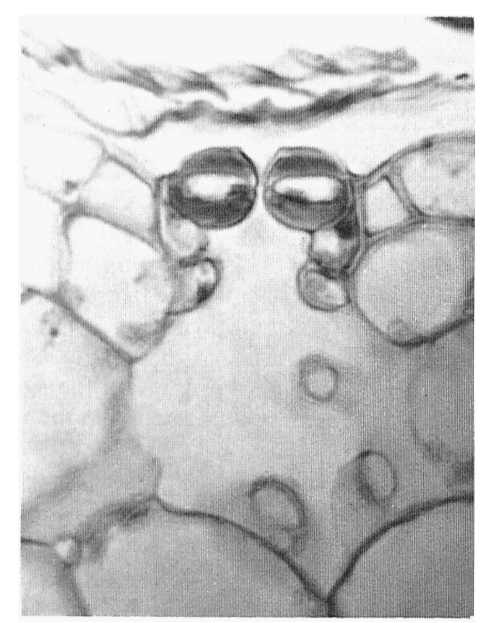

Fig. 5.-Cross section of a leaf of Tillandsia usneoides showing the guard cells with extremely thick cell walls and the large antechamber beneath the stomate. Large mesophyll cells surround the antechamber. Remnants of trichomes are visible above the stomate, which is ca. $50 \mu \mathrm{m}$ wide. 
leaf physiology other than causing stomatal closure. Exogenously applied ABA enhances leaf senescence (ZEIGER 1983); however, given the increasing rates of nocturnal $\mathrm{CO}_{2}$ uptake following ABA treatment in this study, it seems more likely that $\mathrm{ABA}$ directly affected the stomata, and that it was catabolized throughout the night (MILBORROw 1983), allowing stomatal opening. PMA may also disrupt chloroplast membranes (SCHULT and DöRFFLING 1981), which cannot be discounted in our study.

Reports (LINSBAUER 1911; TOMLINSON 1969) of Tillandsia species, including $T$. bryoides, with few or no stomata supported the possibility that functional stomata are not required for regulating gas exchange in atmospheric bromeliads. Such reports probably encouraged the unusual hypotheses concerning the control of gas exchange in these epiphytes (TOMLINSON 1969; DownS 1974; MARTIN 1982; COCKBURN 1983). The presence of stomata on $T$. bryoides leaves was confirmed by the current study as well as by Dr. WERNER RACH (personal communication) and contradicts the previous studies. This finding, in conjunction with the observed sensitivity of nocturnal $\mathrm{CO}_{2}$ uptake to changes in RH (MARTIN and SIEDOW 1981) and the results of the current study indicating that the stomata of the atmospheric epiphyte $T$. usneoides are indeed functional, should eliminate further speculation regarding the control of gas exchange in such epiphytes.

\section{Acknowledgments}

We appreciate the help of W. AdDAMS, D. Bi:N. ZING, C. HAufler, and M. SMITh, as well as one anonymous reviewer, in improving the manuscript. Thanks also go to J. EL.DER, S. HAGiN, and C. SPENCER for assistance in preparation of the manuscript.

\section{LITERATURE CITED}

ARNON, D. I. 1949. Copper enzymes in isolated chloroplasts. Polyphenoloxidase in Beta vulgaris. Plant Physiol. 24:1-15.

Billings, F. H. 1904. A study of Tillandsia usneoides. Bot. GAZ. 38:99-121.

BINGHAM, G. E., and P. I. CoYNE. 1977. A portable, temperature-controlled steady-state porometer for field measurements of transpiration and photosynthesis. Photosynthetica 11:148-160.

BUNCE, J. A. 1981. Comparative responses of leaf conductance to humidity in single attached leaves. J. Exp. Bot. 32:629634.

COCKBURN, W. 1983. Stomatal mechanism as the basis of the evolution of CAM and $\mathrm{C}_{4}$ photosynthesis. Plant Cell Environ. 6:275-279.

Dayanandan, P., and P. B. KaUfMan. 1975. Stomatal movements associated with potassium fluxes. Amer. J. Bot. 62:221-231.

Downs, R. J. 1974. Anatomy and physiology. Pages 2-28 in L. B. SMITH and R. J. Downs, eds. Flora neotropica, Monogr. no. 14 (Pitcairnioideae) (Bromeliaceae). Hafner, New York.

Humble, G. D., and T. C. Hsiao. 1970. Light-dependent influx and efflux of potassium of guard cells during stomatal opening and closing. Plant Physiol. 46:483-487.

JeWER, P. C., and L. D. INCOLL. 1981. Promotion of stomatal opening in detached epidermis of Kalanchoe daigremontiana Hamet et Perr. by natural and synthetic cytokinins. Planta 153:317-318.

JINNO, N., and S. KURAISHI. 1982. Acid-induced stomatal opening in Commelina communis and Vicia faba. Plant Cell Physiol. 23:1169-1174.

Kluge, M., O. L. LANGe, M. V. EichmanN, and R. SChmid. 1973. Diurnaler Säurerhythmus bei Tillandsia usneoides: Untersuchungen über den Weg des Kohlenstoffs sowie die Abhängigkeit des $\mathrm{CO}_{2}$-Gaswechsels von Lichtintensität, Temperatur und Wassergehalt der Pflanze. Planta 112:357372.

LANGE, O. L., R. LÖSCH, E.-D. SCHUIZE, and L. KAPPEN. 1971. Responses of stomata to changes in humidity. Planta 100:7686.

LANGE, O. L., and E. Medina. 1979. Stomata of the CAM plant Tillandsia recuriata respond directly to humidity. (Oecologia 40:357-363.

LinsBaufR, K. 1911. Zur physiologischen Anatomie der Epidermis und des Durchlüftungsapparates der Bromelaacen Sitzungsberichte Math.-Natur. Klasse Kaiserlichen Akad. Wiss. Wien 120:319 - . 348.

MarTin, C. E. 1982. Do stomata control gas exchange in the CAM epiphyte Tillandsia usnerodes i Spanish moss)? Pages 305-306 in I. P. TINo and M. Cilths, eds Crassulacean acid metabolism. American Socicty of Plant Physiolugists. Rex.k. ville, Md.

Martin, C. E., N. L. Christrnshin, and B. R. STRaiN, 19RI Seasonal patterns of growth, tissuc acid fluctuations, and ${ }^{14} \mathrm{C}(\mathrm{C})$. uptake in the Crassulacean acid metabolism epiphyte Til. landsia usneoides I. (Spanish moss). (Necologia 49:322 328.

Martin, C. E., and J. N. Sikixiw. 1981. (rassulactan acid metabolism in the epiphyte Tillandsa usneordes 1. (Spanish moss). Responses of $(\mathrm{O})$ exchange to controlled environ. mental conditions. Plant Physiol 68:3.35 3.39

Martin, C. E., and A. K. ZkE. 198.3. ( . photosynthesis and Crassulacean acid metabolism in a Kansas rexk outcrop succulent, Talinum calycinum Engelm. (Portulacaceac). Plant Physiol. 73:718-723.

Mrz, C. 1896. Monographiae Phanerogamarum Vol. 9. Bromeliaceae. Masson. Paris.

MIlBORROW, B. V. 1983. Pathways $t o$ and from abscisic acid. Pages 79-111 in F. T. Abptort. ed. Abscisic acid. Pracger. New York.

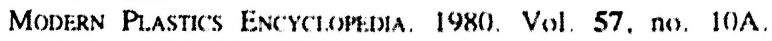
McGraw-Hill, New York

OSMOND, C. B., M. M. L.tDoH, R. Davis, I. R. COHAN, S. B. Powl.ks, and K. Wintr. 1979. Stomatal responses to humidity in Opuntia inermis in relation to control of $(\mathrm{C})$ : and $\mathrm{H}_{2} \mathrm{O}$ exchange patterns. Oecologia $41: 6,56$.

PENFOUND, W. T., and F. G. Dint:R. 1947. On the coology of Spanish moss. Ecology 28:455 458 .

Schul., S., and K. DorkFliNe, 1981. Fvidence against an intermediary role of abscisic acid in stomatal closure induced by phenylmercuric acetate and farnesol. Physiol. Plantarum 53:487-490.

ToMlinson, P. B. 1969. Anatomy of the monexcotyledons. III. 
Commelinales-Zingiberales. Clarendon, Oxford.

Virzo de Santo, A., A. Alfani, and P. De LuCA. 1976. Water vapour uptake from the atmosphere by some Tillandsia species. Ann. Bot. 40:391-394.

WEYERS, J. D. B., and A. J. TRAVIS. 1981. Selection and preparation of leaf epidermis for experiments on stomatal physiology. J. Exp. Bot. 32:837-850.

Wu, H., and P. J. H. Sharpe. 1980. Cell wall mechanics of guard cell motion. Pages 19-46 in C. A. ROGERS, ed. Integrated view of guard cells. So. Sect. Amer. Soc. Plant Physiol.

ZEIGER, E. 1983. The biology of stomatal guard cells. Annu. Rev. Plant Physiol. 34:441-475.

Zeiger, E., S. M. Assmann, and H. Meidner. 1983. The photobiology of Paphiopedilum stomata: opening under blue but not red light. Photochem. Photobiol. 38:627-630.

Craig E. Martin, Anne E. Lubbers, and James A. Teeri. Variability in Crassulacean acid metabolism: a survey of North American succulent species. Published December 1982, pages 491-497.

One of the species we examined on montane rock ledges, Sedum nevii, was incorrectly identified. Dr. CHARLES H. UHL recently collected specimens from our study site and examined our vouchers. He concluded that this species is $S$. ternatum. In the rock-ledge population, we found a small but significant acid fluctuation without nighttime ${ }^{14} \mathrm{CO}_{2}$ uptake, indicative of CAM cycling (sensu STERNBERG et al. 1984); yet we found no acid fluctuation in the forest stream-bank population. With this nomenclatural correction, all species of Sedum thus far investigated exhibit nocturnal accumulations of titratable acid, with (CAM) or without (CAM cycling) concomitant $\mathrm{CO}_{2}$ uptake (TEERI 1982).

Sternberg, L. O., M. J. DeNiro, and I. P. Ting. 1984. Carbon, hydrogen, and oxygen isotope ratios of cellulose from plants having intermediary photosynthetic modes. Plant Physiol. 74:104-107.

TeERI, J. A. 1982. Photosynthetic variation in the Crassulaceae. Pages 244-259 in I. P. TING and M. GibBs, eds. Crassulacean acid metabolism. American Society of Plant Physiologists, Rockville, Md. 